\title{
Divino escenario: los espectáculos de fin de siglo. Il Cromuele
}

\author{
Esther Merino Peral \\ Universidad Complutense de Madrid \\ Dpto. de Historia del Arte II (Moderno) \\ e.merino@pdi.ucm.es
}

Entregado: 20/10/2012

Aceptado: 11/04/2013

\section{RESUMEN}

Si bien, a lo largo de la primera mitad del siglo XVII, reinó en Europa de forma predominante la figura del florentino Giulio Parigi, como exponente de la figura del Escenógrafo, en la creación, diseño, organización y montaje de los espectáculos para los Grandes Duques de Toscana, los Medici, lo cierto es que en la segunda mitad, incluso sobre su modelo de influencia, fueron apareciendo otros focos italianos alternativos en la aportación de artistas y un estilo muy definido dentro del Barroco, en la línea de las "Quadraturas", en su planteamiento de las decoraciones ilusorias para la Escenografía. Es en este ámbito en que se enmarca Il Cromuele de Girolamo, Conde de Graziani, publicado en Bolonia en 1671.

Palabras clave: Escenografía Italiana, Iconografía e Iconología Barroca, Fiesta Barroca, Arte y Arquitectura Efímera, Oliver Cromwell.

\section{Divine stage: spectacle of end century. Il Cromuele}

\begin{abstract}
While, over the first half of the seventeenth century, in Europe predominantly ruled the Giulio Parigi's florentine figure, as an exponent of the scenographer, in the creation, design, organization and assembly of the shows for the Grand Dukes of Tuscany, the Medici, the fact is that in the second half, including its influence model, another's Italian interesting centers were found, providing alternative artists and a very definite style in the Baroque, in line with the "Quadratturas" in its approach to the illusory decorations Set.
\end{abstract}

Key words: Italian Stage Scenery, Baroque Iconographic e Iconologic, Baroque Festival, Ephemeral Art and Architecture, Oliver Cromwell. 


\section{Introducción}

En una época consagrada a la exaltación propagandística de las Monarquías Absolutas, utilizando todos los recursos especulativos y estéticos que posibilitaban las Artes Plásticas, uno de los textos más excepcionales de la Historia del Espectáculo de todo el siglo XVII estaba protagonizado por Cronwell, Oliver Cronwell.

No resulta fácil entender la elección de un personaje, que encarnó la peor pesadilla de los reyes de los Estados Modernos ${ }^{1}$, quienes durante varias centurias lucharon por todos los medios por afianzar su poder y por la legitimación dinástica, ya fuera mediante la promoción de intelectuales que elaboraran árboles genealógicos de dudosa ascendencia o con la celebración de diversos festejos en los que se sacaron a pasear por el escenario urbano un colosal retablo iconográfico de iconológica semblanza, siempre a mayor gloria de sus estirpes, en lo que se ha denominado la Lúdica del Poder.

Por eso mismo resultaba un tanto incomprensible esta magna obra en torno a quien dirigió los destinos de la Gran Bretaña con afanes liberticidas, adelantándose más de un siglo a la Revolución Francesa, logrando la condena del rey Carlos I Estuardo, quien por ende, perdió la cabeza en el cadalso, e instaurando una Dictadura bajo la apariencia de una Pseudo República Parlamentaria.

Carlos I, hijo de Jacobo o Jaime I, gobernó sin acuerdo con el Parlamento entre 1629 y 1640, imponiendo una política absolutista, a la manera de sus homólogos europeos, como su cuñado Luis XIV, aumentando las prerrogativas de la aristocracia en perjuicio de la naciente burguesía. Declarada la guerra civil entre realistas y partidarios de la soberanía parlamentaria, fue Sir Thomas III Lord Fairfax (1612-1671) el verdadero artífice de las victorias de los denominados Puritanos, al mando de un ejército profesional, sometido a una estricta disciplina militar, con el que logró las victorias definitivas en Marston Moor primero, en 1644, y en Naseby después, en junio de 1645. A partir de ese momento comenzaron las disensiones con Ireton y Cronwell, principales cabecillas de la revuelta y radicales partidarios de la muerte del rey como único comienzo de una nueva era. Oliver Cronwell (1599-1658), sobrino nieto del otro Cronwell famoso en el siglo XVI, había sido criado en un ambiente puritano y profundamente anticatólico, e incluso quiso emigrar a los Estados Unidos en busca de territorios vírgenes y más proclives a la pureza espiritual y gubernamental antagónica a la que se vivía con la instauración de los Estuardo en el trono de Inglaterra.

Con todo se concibió Il Cronwele en la década de 1670. En 1671 más concretamente firmó la dedicatoria su autor, si bien es cierto que no se tenían noticias de que

1 En España también se intentaba estar al corriente de las acciones de Cromwell. El personaje que había osado atentar contra la figura sacrosanta del monarca absoluto, lógicamente había de suscitar interés en el resto de las monarquías europeas y siguió haciéndolo a lo largo del siglo XVII. Para muchos resultaba un misterio insondable que esto pudiera llegar a suceder, antecediendo casi un siglo a la que se considera la "madre de las revoluciones", la Revolución Francesa. Y en la España de los Habsburgo, el personaje estaba muy presente con las constantes menciones de los cronistas de la época, tal y como se puede comprobar en los Avisos de Jerónimo de BARRIONUEVO (1654-1658), Biblioteca de Autores Españoles II, Edición y estudio preliminar de A. PAZ y MELIA, Madrid 1969. 
fuera llevada al escenario hasta la versión que de la obra hiciera Víctor Hugo en el siglo XIX.

Todo en torno a este asunto parecía contradictorio. Una obra concebida en Bolonia, uno de los antaño Estados Pontificios, a mayor gloria del Príncipe de la Iglesia, entonces devenido en parte del Ducado de Módena, cuyo trasfondo, sin embargo, narraba la Historia de la Revolución Inglesa, en la que, entre otras consecuencias de años de guerra civil, además de la decapitación regia en 1648, se abolió formalmente la Cámara de los Lores, adoptándose por la única asamblea parlamentaria considerada legítima, la Cámara de los Comunes, una resolución en los siguientes términos: " $L a$ experiencia ha demostrado que la dignidad del rey es en este país inútil, onerosa y peligrosa para la libertad, la seguridad y el bien del pueblo, en consecuencia queda abolida desde este día" ${ }^{2}$. Es verdad que la Reforma del autoproclamado Lord Protector no duró mucho y con la Restauración del Príncipe de Gales, el que fuera Carlos II, el cadáver de Cronwell se sacó del sepulcro y fue expuesto para su oprobio público, transmitiendo la idea de la fugacidad según la fórmula emblemática de las Vanitas, todo lo cual no impidió el enorme estupor que recorrió Europa ante los hechos acaecidos.

Girolamo, Conde de Graziani, a la sazón secretario y consigliere del Duque de Módena según reza en el frontis, fue el autor del texto que se imprimió en Bolonia en 1671 en la prensa de los Manolesi, siendo uno de los escasos ejemplos de Tragedias de temática contemporánea.

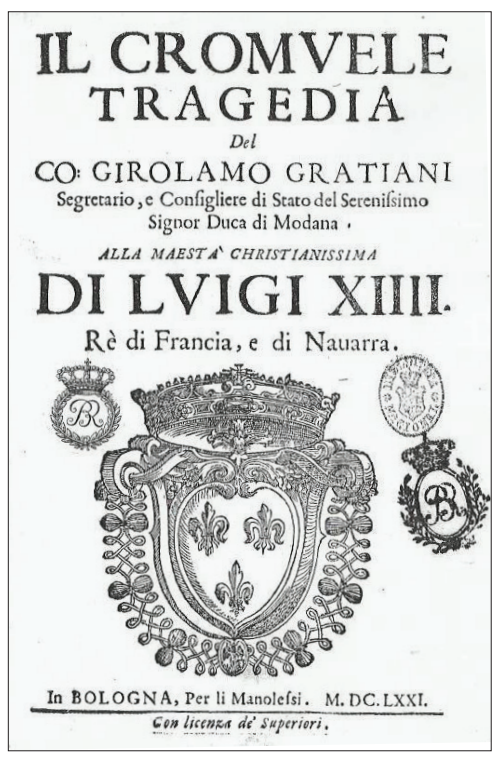

Fig. 1. Portada de la obra. BNE.

2 François GUIZOT, Historia de la Revolución de Inglaterra. Desde el advenimiento de Carlos I hasta su muerte, Barcelona 1986, p. 313. Ver también Peter GAUNT, Oliver Cronwell, Massachusetts 1996. 
El ejemplar de esta obra, que se conserva entre los fantásticos fondos de la Biblioteca Nacional de Madrid tiene un ex libris manuscrito en la hoja de guarda posterior en el que se menciona a Perafán de Rivera pero llega procedente de la Biblioteca del Palacio Real, según se deduce de los sellos que aparecen estampados junto al escudo blasonado de flores de lis de la xilografía de la portada, que acompaña la dedicatoria al rey de Francia Luis XIV, hermano de Enriqueta María, esposa del finado rey inglés decapitado. El rey Sol podía vanagloriarse de ser el más absoluto de los monarcas absolutistas de la época, en torno al cual se gestó un protocolo de celebraciones cuyo objetivo fundamental incidía en la abundancia emblemática de exaltación de su persona y de su gobierno. Cualidades que servían para explicar algunas de las palabras de dicha dedicatoria, en la que se dice que "sì come Vostra Maestà in questo gran Teatro dell'Universo è nelle di lei ammirabili qualitá la vera Idea di un perfecto Heroe da celebrarsi con una Epopeia per esemplare d'imitatione à quei Monarchi, che aspirano di poggiare all 'Immortalitá per le vie dell'Honore, cosí questa mia Tragedia esposta alla publicità delle stampe..." [puesto que personaliza Vuestra Majestad la figura del Héroe en este gran Teatro Universal era necesario celebrarlo con una Epopeya para ejemplo de aquellos monarcas que aspiran a la inmortalidad a través del ejercicio del Honor y es para su difusión por lo que ha sido llevada esta obra a la imprenta...]. Tragedia y Epopeya precisamente son las personificaciones femeninas, coronadas por la Victoria alada, que aparecen en la imagen de la calcografía entre los preliminares previos a la narración.

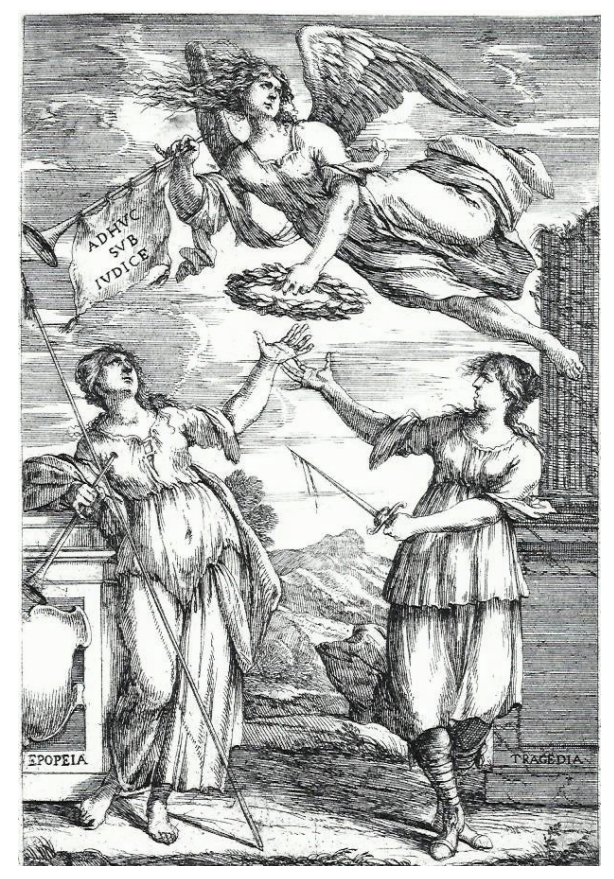

Fig. 2. Calcografía de los Preliminares. Personificación de Epopeya y Tragedia. 


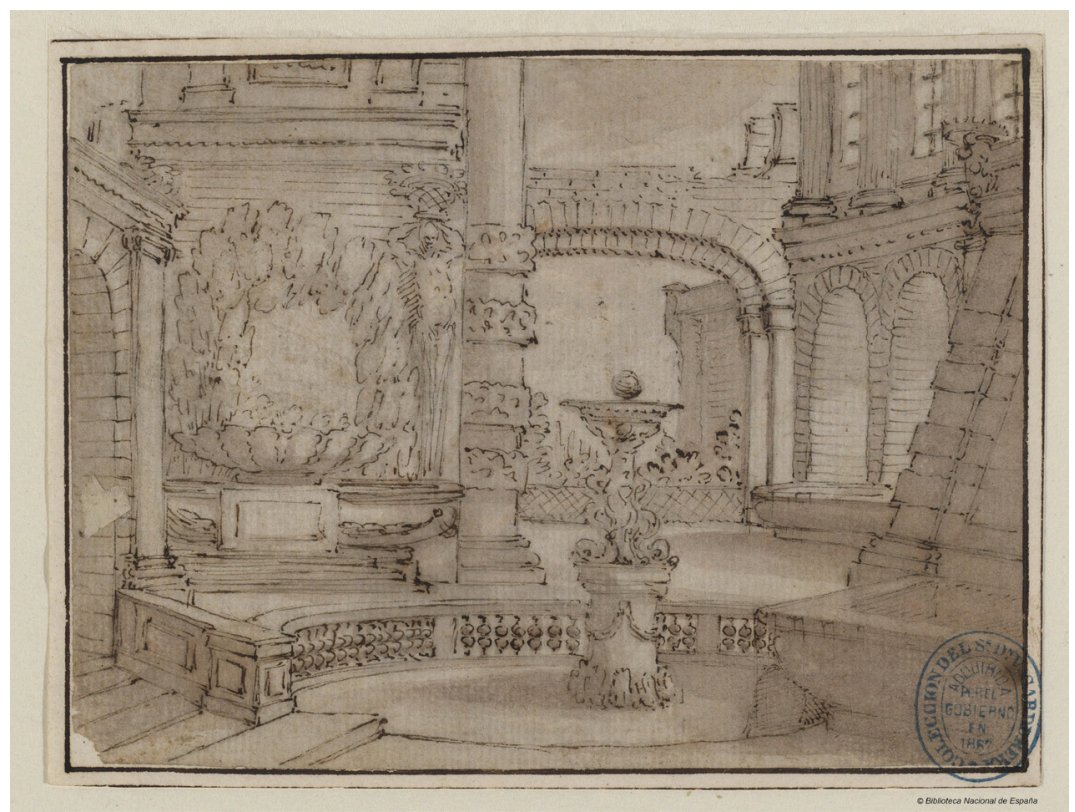

Fig. 3. Decoración escenográfica. Atribuido a Agostino Mitelli. BNE.

Sin embargo, no es de extrañar que Graziani ${ }^{3}$ (1604-1675), le brindara el texto al rey de Francia, puesto que había sido bajo sus auspicios gracias a los cuales se había logrado la empresa en la que tanto empeño había puesto el diplomático de concertar el matrimonio entre María Beatrice d'Este descendiente del Cardenal Mazzarino y el Duque de York, quien llegaría a reinar en Inglaterra como Jaime II. Así que todo lo relacionado con esta obra, a manera de homenaje, venía a reparar de alguna manera el descalabro de una historia regia que al final terminaba bien. Graziani llegó a conocer muy bien la corte francesa, delegado por su patrón Francesco I d'Este entre 1648 y 1655, por lo cual fue premiado con una considerable pensión por el Rey Sol. Y, por si fuera poco, también llegó a formar parte de algunas de las instituciones eruditas más prestigiosas de la época, como fueron la Academia della Crusca, Gelati e Incogniti.

También en Madrid, dentro del catálogo de la Biblioteca Nacional (BNE), se menciona un dibujo titulado "Decoración escenográfica"4, que en el desglose específico correspondiente, consta como "Decoración de un techo", que Barcia al parecer consideraba como obra anónima española del siglo XVII. J. M. Bardeito lo atribuye a

3 Afamado escritor y diplomático, también fue autor de las obras tituladas Il conquisto di Granata (1650), poema heroico con argumento de Flaminio Calvi y La Cleopatra (1653), de los que se encuentran sendos ejemplares entre los inestimables fondos de la Biblioteca Nacional de Madrid (BNE). Si bien es cierto que su fama vino de la mano de una de sus obras más reconocidas, Trionfo della Virtù, un baile ecuestre que se celebró en Módena el 12 de junio de 1660, con música de Benedetto Ferrari, Maestro de Capilla Palatina, con el que se conmemoraba el Bautismo del príncipe y futuro Duque Francesco II.

4 Figura en el Catálogo de la BNE como su autor Agostino Minelli (1609-1660), realizada en unas fechas aproximadamente entre 1636 y 1641. 
Agostino Mitelli, que junto a Angelo Michele Colonna viajaron a la España de Felipe IV, adscribiéndolo Virginia Tovar al círculo de decoradores barrocos que interpretaban a los boloñeses por sus similitudes estéticas. Por su parte, fue descartado por R. Raggi como obra de ambos artistas e incluso rechazándolo como presumible diseño para las decoraciones del Salón de los Espejos del Alcázar de Madrid. Lo cierto es que, siendo de notable belleza, la composición similar a otros diseños de verzura ajardinada para ilustrar montajes teatrales, columnas anilladas y alardes perspectivos arquitectónicos, incluso muestra un gran arco que recuerda a los de Embocadura de proscenio, todo lo cual, en todo caso, indica el interés de la Corte española por los artistas florentinos en un primer estadio y boloñeses a partir de la segunda mitad del Seicento, quienes en la estela de Buontalenti y Parigi, constituyeron un grupo de profesionales, de gran pericia en la creación de decoraciones para la Fiesta Efímera, tanto en el marco urbano como en el escénico propiamente. Así se justificaría, también desde el punto de vista estilístico, la presencia de la obra de Graziani entre los fondos que desde el Palacio Real terminaron depositados en la Biblioteca Nacional de Madrid.

\section{Historia de la Escenografía y del Espectáculo}

Se ha podido constatar el origen de la simbología metafórica del Teatro Renacentista en los géneros del Mimo y Pantomimo Romano ${ }^{5}$. El Renacimiento del Teatro como institución profana, desligado del espectáculo sacro medieval, surgió sobre todo a partir de la recuperación de los textos de Plauto y Terencio, y a partir del Decamerón de Bocaccio ${ }^{6}$. Esta obra imprimió un nuevo impulso por su diferente estructura teatral, con su trama, a la hora de buscar una nueva escenografía. Personajes y simbología propia de la escenografía romana contribuyeron a la creación de la comedia humanística, ambientada en las ciudades, sobre fondo de edificios reconocibles de la geografía urbana real y luego tipificadas por la normativa clásica. Teatro profano como manifestación de la cultura humanística, apoyada en un nuevo repertorio escenográfico y técnicas teatrales.

La especialidad escenográfica creó estereotipos figurativos. "Topos scenografici"7. La clase patricia italiana descubrió pronto que con la responsabilidad político-administrativa se lograban grandes ventajas económicas, y dentro de este ámbito hay que encuadrar el interés por las posibilidades de gestionar la cultura y el espectáculo.

\footnotetext{
5 Luca GRAVERINI, "La scena raccontata: teatro e narrativa antica", en Francesco MOSETTI CASARETTO, La scena assente. Realtà e leggenda sul teatro nel Medioevo. Atti delle II Giornate Internazionali Interdisciplinari di Studio sul Medioevo (Siena, 13-16 giugno 2004), Serie Ricerche Intermedievali, Ed. Dell'Orso, Alessandria 2006, pp. 1-17.

6 Paolo VITI, "Scena, attori e rappresentazione nelle prime commedie umanistiche", en Francesco MOSETTI CASARETTO, La scena assente. Realtà e leggenda sul teatro nel Medioevo..., op. cit., pp. 505525 .

7 Anna M. TESTAVERDE, "Episodi di architettura effimera e stereotipi iconografici di Firenze tra i secoli XVI-XVIII", en J. de LA GORCE, Iconographie et arts du spectacle, Histoire de l'art et iconographie, Actes du Séminaire CNRS, París, Klincksieck 1996, pp. 29-58.
} 
La península italiana vivió el Seicento, el siglo XVII, como su "grand siècle" de sustancial unidad cultural, que sin embargo se ha afrontado de forma fragmentada por la investigación, cuando debía haberse concluido la solidaridad entre las artes del espectáculo y las artes figurativas. Se hace necesaria, por tanto, una Historia del Espectáculo como forma de integración de las Artes, en la que el Escenógrafo prefigura al artista total. Una Historia del Espectáculo como disciplina historiográfica, en la que se inserte la "mentalidad escenográfica", en la que Perspectiva y Escenografía fueran "dos elementos de la misma retórica", como síntesis escénica y así favorecer la comprensión de la codificación serliana como abstracción o suma de una práctica establecida como tipología. Por todas estas razones debería enfocarse la aproximación al Origen del Teatro Renacentista como un estudio de la Perspectiva, de la capacidad dramática, de la investigación artística y restitución de las Artes Plásticas de la Antigüedad y del Teatro Vitruviano ${ }^{8}$.

\section{Los Medici y sus Escenógrafos}

La grandeza de los Medici, hábiles en lo que puede denominarse juegos ilusorios, fue posible gracias a las labores de los escenógrafos, los artistas totales, multiédricos les ha llamado alguien. Giorgio Vasari, Bernardo Buontalenti, Giulio Parigi, Alfonso Parigi, Ferdinando Tacca, Giacomo Chiavistelli y Antonio Ferri ya a caballo del otro siglo, el Ottocento. Gloriosos nombres de quienes, como precursores, hicieron posible ese sueño. El reino de la Ilusión.

En Italia, los Medici tuvieron la perspicacia y habilidad de estimar la belleza, de dotarse de los medios para vivir en unas residencias fabulosas, pero también de insertar de forma visionaria, toda esa estética en un conjunto de fuerte simbología política, que supieron manipular magistralmente como los Romanos a lo que siempre quisieron emular en la grandilocuencia de sus ceremonias, civiles o religiosas, y es ahí donde radica la importancia de estos artistas totales que fueron los Escenógrafos. Y Florencia tuvo su época dorada en el Renacimiento, pero la culminación de conocimientos aplicados a la ostentación del poder áulico tuvo especial florecimiento en el Seicento. Sin duda alguna, el siglo XVII es el del esplendor florentino y el siglo XVII hispano, nuestro Siglo de Oro es el de la preeminencia de los modelos de influencia florentinos.

\section{Florencia y España}

Sin embargo, parece increíble que los estudios sobre Arte Efímero y Escenografía más precisamente se hayan retrasado en la historiografía hispana. En líneas generales se vieron identificados con los prejuicios del Barroco, pero empezaron a gozar de

8 Sara MAMONE, “Arte e spettacolo: la partita senza fine”, en J. de LA GORCE, Iconographie et arts..., op. cit., pp. 59-134. 
nuevas interpretaciones y revisiones a partir de los años sesenta en Italia ${ }^{9}$. La Teatralidad, la exageración del histrionismo y del gesto trasladados a la esfera social, conceptos como los de apoteosis, de multiplicidad iconológica, todo lo cual parecía envuelto en connotaciones negativas, pero de un tiempo a esta parte se empieza a profundizar en el valor de las Artes Plásticas como instrumento áulico, doctrinal y propagandístico, demostrable en los esfuerzos de las principales cortes europeas por el mecenazgo de lo que se ha venido en llamar la lúdica del poder absolutista.

En ese ámbito, Florencia, convertida en verdadero escenario urbano, ejerció un papel preeminente y la España de los Austrias fue uno de los lugares en los que mejor se difundieron iconografía, protocolo de celebración y artistas, algunos de ellos directamente demandados a la propia corte medicea. Así, de los principales escenógrafos anteriormente mencionados, que dominaron la escena del Espectáculo florentino del siglo XVII ${ }^{10}$, se encuentran noticias documentales en archivos y bibliotecas madrileños. Concretamente, la Biblioteca Nacional de Madrid, es uno de los centros bibliográficos más relevantes, porque en ella se localizan testimonio de los que fueron montajes más significativos de la Florencia de los Medici del Seicento.

En cuanto a los protagonistas, Bernardo Buontalenti ${ }^{11}$, de hecho, incluso pasó por Madrid $^{12}$. Vasari se ocupó de la organización de la práctica ejecución de los festejos en honor de Cosme II, utilizando para ello el espacio del Teatro de los Uffizi. Y con él se formó el que fuera el gran "capo" de la escenografía de las primeras décadas del siglo XVII en la corte florentina, Giulio Parigi. Uno de los grandes desconocidos aquí. De él se conservan, entre otras, muestras gráficas de sus montajes más famosos, grabadas por Callot, que fue discípulo suyo en su Academia de Via Maggio, que ilustraban la denominada Guerra del Amor y de la Belleza, de los Intermezzi para la representación de la Liberación de Tirreno, Santa Úrsula y el Solimano.

Este personaje, que ya se adivinaba uno de los más interesantes de la escenografía florentina, se ha confirmado no sólo como tal, sino como verdadero Valido en su status de Artista de la Corte de los Medici de la primera mitad del siglo XVII. Era presumible, analizando el fondo iconológico de algunas de sus obras más significativas, que habían llegado hasta Madrid. Pero, lo cierto es que crece el conocimiento de la magnitud de su labor y de lo que fue su preeminencia creando una estética, un gusto por determinadas ceremonias y usos artísticos, cuya difusión fue todavía más amplia, dado que se ocupó igualmente de la formación, a través de su magisterio en el que fuera el domicilio de Buontalenti y después el suyo propio, muy cerca del Pa-

9 María T. MURARO (a cargo de la recopilación de estudios de varios autores), Studi sul Teatro Veneto fra Rinascimento ed età barocca, L. Olschki editore, Florencia 1871.

10 Carlo Enrico RAVA, "Influssi della scenografia italiana pre-barocca e barocca in Inghilterra e in Germania (Iñigo Jones-Francisco Santurini), en Antichità Viva, 1969, 3, pp. 42-55.

11 Alessandra BUCCHERI, "Il ruolo della scenografia da Bernardo Buontalenti a Giulio Parigi", en Mina GREGORI, Il Seicento, Cassa di Risparmio di Firenze, Florencia 2001, pp. 21-28.

12 Al parecer, el genial artista florentino acompañó al Gran Duque de Toscana Ferdinando I, en su viaje a España en 1562 y ofreció algunas de sus creaciones a manera de presentes al rey Felipe III. Se recogen informaciones sobre escenógrafos italianos de los muy interesantes trabajos de Teresa FERRER y Mª Asunción FLÓREZ, en E. MERINO, "La repercusión de la Escenografía italiana en el espectáculo cortesano español del siglo XVII: Divino Escenario”, Historia de la Escenografia en el siglo XVII: creadores y tratadistas, Secretariado de Publicaciones de la Universidad de Sevilla, Sevilla 2011, pp. 153-167. 
lazzo Pitti. A través de sus discípulos predilectos, Callot, Della Bella, Cantagallina, Furttenbach, Lotti e Iñigo Jones, se transmitieron sus enseñanzas, su concepto de la Escena, al resto de las principales cortes europeas del Barroco. Es comprensible, por tanto, que en la Corte de los Austrias españoles hubiera notable interés por emular las fórmulas que propiciaron, de la mano de Parigi, la creación del Estado Florentino, de una entidad política de tintes monárquicos, en base a la Escenografía y de las Artes Escénicas, como instrumento indispensable. Una de las fuentes de conocimiento de lo que fue tan relevante personaje, ha sido, indudablemente, su Testamento, conservado en el Archivio di Stato de Florencia, redactado en 1634, así como el "Privilegio", nombramiento concedido en 1623 por Ferdinando II, que describía los trabajos de Parigi ${ }^{13}$ en la Corte, así como las posesiones de las que llegó a disponer gracias a las mercedes de sus mentores y mecenas, contenidos ambos dentro de lo que se conoce como "Il Taccuino" o Recuerdos, con información de la familia entre 1565 y 1660.

A Callot, grabador e ilustrador de los espectáculos cortesanos de Parigi, le sucedieron Stefano della Bella y Aernout van Westerhout. Y en el cargo de Escenógrafo y Artista de la Corte, su hijo Alfonso Parigi y a él otro de los discípulos del padre, Ferdinando Tacca, del que se localiza en la misma Biblioteca Nacional Madrileña, un ejemplar de la que fuera una de sus obras más conocidas en la época, la Ipermestra, que se representó en el Teatro de la Pérgola, en la calle del mismo nombre, en Florencia, que construyó él mismo, después de visitar numerosos edificios en Toscana y Romaña, ya que para esas fechas, rebasada la segunda mitad del siglo, los artistas boloñeses en la órbita de los Quadraturistas, Colonna y Mitelli, que luego recalaron en España posteriormente, habían tomado el relevo en la innovación teatral. Quadratturas que generan un espacio virtual ${ }^{14}$ y que abren nuevas posibilidades a la representación ilusionística ${ }^{15}$. Precisamente, de ese ámbito se deduce la presencia de $\mathrm{Il}$ Cromuele, con libreto de uno de los eruditos más relevantes de los círculos ilustrados florentinos, como los Incogniti, y boloñeses al tiempo, Girolamo Conte de Graziani. A esas alturas, junto a Graziani, fueron muchos los "libretistas" de los espectáculos florentinos, como Moniglia o Mateo Noris, vinculados con las numerosas Academias, algunas ya mencionadas, encargadas de crear el ideario de la Fiesta Barroca, como de los Incostanti, Rinvigoriti, Sorgenti o Infuocati.

Por su parte, Tacca viajó en 1642 a la Península Ibérica ${ }^{16}$, acompañando la escultura ecuestre que para monarca Felipe IV había realizado su padre Pietro Tacca por encargo del Conde Duque de Olivares para el Sitio del Buen Retiro y también recibió otros tantos encargos antes de regresar a Florencia. Después fue Jacopo Chia-

13 De imprescindible consulta la biografía de A. BLUMENTHAL, Giulio Parigi's stage desings: Florence and the early baroque spectacle, New York, Garland 1986.

14 Fauzia FARNETI, "Quadraturismo e grande decorazione nella Toscana granducale", en Mario BEVILACQUA y Giuseppina C. ROMBY, Firenze e il Granducato, Atlante del Barocco in Italia, Roma, De Luca 2007, pp. 205-233.

15 Esther MERINO, El reino de la ilusión. Breve historia y tipos de espectáculo. El arte efímero y los orígenes de la Escenografia, Monografías de Arquitectura 1, Servicio de Publicaciones de la Universidad de Alcalá, Alcalá de Henares 2005.

16 Luigi ZANGHIERI, “Artisti toscani per la corte di Spagna”, en Antichità Viva, 35, 1996 (1997), 4, pp. 14-20. 
vistelli ${ }^{17}$ el artista que se ocupó de la creación y ejecución práctica de los montajes para los Medici, a finales del siglo. De él se conserva en la BNE su obra $\mathrm{Il} \mathrm{Greco} \mathrm{in}$ Troia, con libreto de Noris y publicado en 1678, cuyos aparatos fueron ideados por Antonio Ferri ${ }^{18}$, conocido incluso como profesional "Aparatori" y quien encarnó al escenógrafo del cambio de centuria y que se había formado en la "bottega" o círculo de Chiavistelli.

En el contexto boloñés en ciernes, no sólo Colonna y Mitelli resultaron determinantes, contribuyendo a la difusión de los parámetros escenográficos en España, sino que también pertenecen a ese ambiente los Vigarani, los Burnacini y los Bibiena, emparentados con el concepto ilusionístico en base a la multiplicidad perspectiva, que desarrolló en Venecia otra de las grandes figuras del siglo, Torelli, quien a la postre, terminó por ser el artífice del género operístico en los Teatros Venecianos y de su difusión en la Corte de Luis XIV, en la que también se gestó el Ballet du Cour, gracias a la integración de las decoraciones de los Vigarani y de la danza creada por Lully, nacido a su vez en el Lungarno de Americo Vespucci en Florencia. De Torelli se puede encontrar ejemplar de una de sus obras más espectaculares, el Bellerofonte en la BNE, y de Ludovico Burnacini asimismo ejemplares de Il Pomo d'Oro y de Il Fuoco Eterno, a través de las que se trasladó el espíritu de la escenografía italiana por Centroeuropa.

En Florencia, por tanto, se gestaron algunos de los géneros fundamentales de la Historia del espectáculo, como el Melodrama, nacido, para algunos, como resultado de la recuperación de la tradición oculta, que no perdida, del clasicismo musical de la Antigüedad, Tales espectáculos y los géneros a ellos asociados, que fueron codificándose, llegaron a formar parte indisoluble no sólo de la cultura, sino del comportamiento social.

\section{El espectáculo en Bolonia}

En mayo de 1654 el Cardenal Giovanni Carlo de Medici, encabezaba por entonces la iniciativa personal de edificar en Florencia un teatro, en Via della Pergola, en el marco de las actividades culturales de la Academia de los Inmobili. Para ello había enviado al arquitecto Ferdinando Tacca, encargado de su construcción, a visitar los más célebres de Lombardía, en particular los de Parma y Bolonia. A mitad de siglo, las ciudades de la Emilia podían ofrecer modelos prototípicos de salas de espectáculos incluso a los arquitectos de Florencia, indiscutible capital del Teatro. Parece demostrado que Tacca se benefició de los avances del Teatro Farnese de Parma, el más vanguardista en cuanto a técnicas, maquinaria y diseños visionarios utilizados en los montajes allí celebrados. Más que meras representaciones, en el Teatro del ferrarés Aleotti se conmemoraron verdaderas apoteosis de Arte Efímero, con todos los medios disponibles formalmente y de vasta significación en las interpretaciones de sus contenidos. Por eso, desde fechas

17 Fabia BORRONI SALVADORI, "Cerimonie e feste sotto gli ultimi Medici, 1670-1743", Antichità Viva, 13, 1974, 2, pp. 48-61.

18 Luigi ZANGHIERI, “Antonio Ferri. Architetto granducale”, en Antichità Viva, 11, 1972, 6, pp. 45-56. 
tempranas, se había convertido en un modelo a estudiar y emular, por los florentinos interesados en la cuestión, quienes, además, lo reconocían como la lógica evolución de los preceptos ensayados anteriormente por Buontalenti y Vasari. La zona de Bolonia tenía, a su vez, dignos exponentes del edificio farnesiano, como la Sala de Comedias de Reggio, presumiblemente reestructurado por Gaspare Vigarani, a quien se le deben también ejemplos como los Teatros de Carpi y Módena, antes de exportarlo a Francia en forma de las célebre Salle des Machines, en la corte de Luis XIV. En Bolonia expresamente existían varios edificios adaptados a esos usos, como la Casa Zoppio donde solía reunirse la Academia de Gelati o el Teatro Formagliari de Andrea Seghizzi, este último especializado en montajes musicales y el Teatro de la Sala o del Podestá, donde se habían celebrado representaciones de varios tipos, como torneos, óperas, y durante un tiempo incluso fue destinado a comedias y espectáculos "menores" orientados a un público popular, quizás menos instruido en los sutiles mensajes eruditos tras las imágenes de géneros de ámbito puramente cortesano.

En Bolonia, el Renacimiento Teatral aparece igualmente ligado a los círculos culturales humanísticos de la órbita aristocrática y académica, ya rastreables a finales del siglo XV. En la primera mitad del Cinquecento, quizás a causa de la decadencia precoz de los Bentivoglio, la segunda ciudad de los Estados Pontificios pasó a estar bajo supervisión política y artística de los dictados florentinos. Obviamente, no dejó de ser escenario de momentos sublimes como la Coronación de Carlos V en 1530, pero está claro que no podía competir, aún manteniendo cierta regularidad en la representación de comedias y tragedias, con el creciente esplendor espectacular de la corte medicea en Florencia. La tendencia se invirtió, precisamente, rebasada la mitad del Seicento, puesto que la efervescencia artística se mantuvo latente, de manera que para esas fechas Bolonia se incorporó con fruición a las directrices del moderno sistema teatral, que solventaban asimismo los intereses de las familias patricias más relevantes, en sus afanes por mantener los privilegios y ventajas económicas derivados de sus responsabilidades administrativas, beneficiándose para ello también de la gestión de la cultura representativa.

Se fueron regularizando festejos en fechas fijas del calendario celebrativo y en espacios específicos del escenario urbano, como los Torneos o la Giostra, que requerían la construcción no sólo de las gradas para la ubicación del público, sino de las decoraciones efímeras al efecto de ilustrar la ambientación de los distintos eventos. A lo largo de las primeras décadas del siglo XVII se fue asentando la célebre Porchetta, que ya requirió un espacio formal más ajustado a la nueva tipología teatral, asociado a un edificio independiente y autónomo a la manera de los que se habían ido creando en el siglo anterior, como el de Vicenza de Palladio, conocidos por sus características en base a la perspectiva en torno a la cual se organizaban decorados y maquinaria adaptada, como teatros a la italiana. Pese a la incipiente presencia del edificio teatral concebido para usos a largo plazo, con todo, en Bolonia, persistieron los usos y costumbres basados en las decoraciones efímeras en torno a la fórmula del Torneo. Éste no era solamente la manifestación de fortaleza de caballeros que dirimían sus disputas por ese cauce y que podían saldarse, incluso con la muerte de uno de los ilustres contendientes, como le ocurrió al rey de Francia Enrique de Valois. Más que eso, el Torneo era una ocasión de 
amplio espectro, que con el paso del tiempo dejó atrás los preceptos de la caballería pesada para convertirse en plataforma de la escenoplástica cortesana, que ya a finales del Medievo era conocido como Torneo Temático, como el célebre de Binche ${ }^{19}$, al que se asociaban banquetes, mascaradas y representaciones teatrales, que podían ambientarse tanto en el contexto interior palatino como en el urbano más populoso y es éste último el que tuvo mayor fortuna a lo largo de la historia del espectáculo boloñés. Es relevante la expresión del Torneo porque en su seno se gesta la Ópera. Al Torneo se le fueron ampliando fronteras que requerían un marco más flexible que abarcara movimiento, recital y baile o coreografía e incluso demostración de cualidades vocales con unas decoraciones asociadas progresivamente más ricas y sorprendentes. Y así fue creándose la Ópera-Torneo. Del caballero andante se fue perfilando la figura del artista protagonista cantante, sobre todos los cuales se sobrepuso el escenógrafo, hábil en la planificación de tan difícil y arduo programa que soportaba la urdimbre de la trama, la ambientación y representación.

En Bolonia había por tanto una extensa tradición lúdica, entre los que merece la pena mencionar algunos títulos significativos, como el Torneo de Il castello di Gorgoferusa o el de La Montagna Circea Y la aristocracia boloñesa no fue ajena a la persistencia de este género, ya que así creían mantener latentes y vigentes los ideales caballerescos, contribuyendo por su parte a la causa con la fundación Academias eruditas, como la de la Viola, que se ocuparon de la organización de festejos como el denominado Torneo fatto sotto il Castello d'Argio da SS. Cavalieri Bolognesi il dì IX febraio di 1578.

En ese proceso se fueron estampando algunos grabados con ilustración de lo que fueron tales montajes y máquinas o ingenios empleados, que destacaron por su efectismo, hasta llegar a la publicación del libreto necesario para comprender argumentos, tramas e interpretaciones de enorme complejidad y sutileza escondidos tras las imágenes expuestas a ojos de los maravillados espectadores, generalmente de provecho propagandístico para el comitente de los festejos. Es en este contexto en el que se mencionaba el nombre de Guglielmo Fava como "intendente sovra la mediocrità di cose di prospectiva e di architettura, in materia di fuocchi singolare, efficace nell'immaginare e risoluto nell'effettuare" 20 .

En la relación de fiestas del siglo XVII, muchas de ellas indefectiblemente ubicadas con sede estable en el Teatro de la Sala, se mencionan a otros tantos "artífices" o creadores de las "invenciones" para las decoraciones, como Gabriele Guidotti y el pintor Giovanni Valesio ${ }^{21}$, al que se calificaba más concretamente como "intendente alle machine". En la década de los treinta y los cuarenta, se le atribuía el patrocinio y promoción del marqués Cornelio Malvasia de grandiosos montajes en la senda de los

19 Roy Strong, "Carlos V y el viaje imperial: Los festivales de Bains, 1549: el libro de caballerías y el soberano", en Arte y poder, Alianza Editorial, Madrid 1988, pp. 99-104

20 Deanna LENZI, "Teatri ed anfiteatri a Bologna nei secoli XVI e XVII", en Maurizio FAGIOLO y Bruno ADORNI, Barocco romano e barocco italiano. Il teatro, l'effimero, l'allegoria, Roma, Gangemi 1985, pp. 175-191. Ver también Marinella PIGOZZI, "Bologna e le città d'Emilia in festa", en Marcello FAGIOLO e Carlo COCCIOLI, Il gran teatro del Barocco: le capitali della festa, Atlante del Barocco in Italia, Roma, De Luca 2007, pp. 12-26.

21 Deanna LENZI, “Teatri ed anfiteatri...”, op. cit., pp. 183-184 respectivamente. 
que por entonces reinaba el genio creativo de Giulio Parigi ${ }^{22}$ en Florencia, como de hecho, incluso, se hizo con Il Solimano en 1637, para lo que se sirvió de la experiencia y notables habilidades de Francesco Guitti y Alfonso Rivarola conocido como Chenda, reputados artistas devenidos en escenógrafos en el área de Ferrara, Padua y Parma.

\section{El Cromuele}

Al parecer, en 1670 el Marqués Silvio Molza, Gobernador a la sazón de Reggio, hizo recitar esta Ópera en casa de los Masdoni, por algunos de los caballeros de la zona ${ }^{23}$ que eran sus huéspedes. Los Masdoni eran cortesanos de los Este y embajadores en la sede papal, que por entonces habitaban un edificio Quattrocentesco, remodelado a finales del siglo XVII por el arquitecto Giovanni Battista Ferraroni (1662-1755), con una sala habilitada como teatro decorado con angelotes por Francesco Vellani (1688-1768) y perspectivas fingidas ya a lo largo del Settecento por Fernando y Francesco Bibiena.

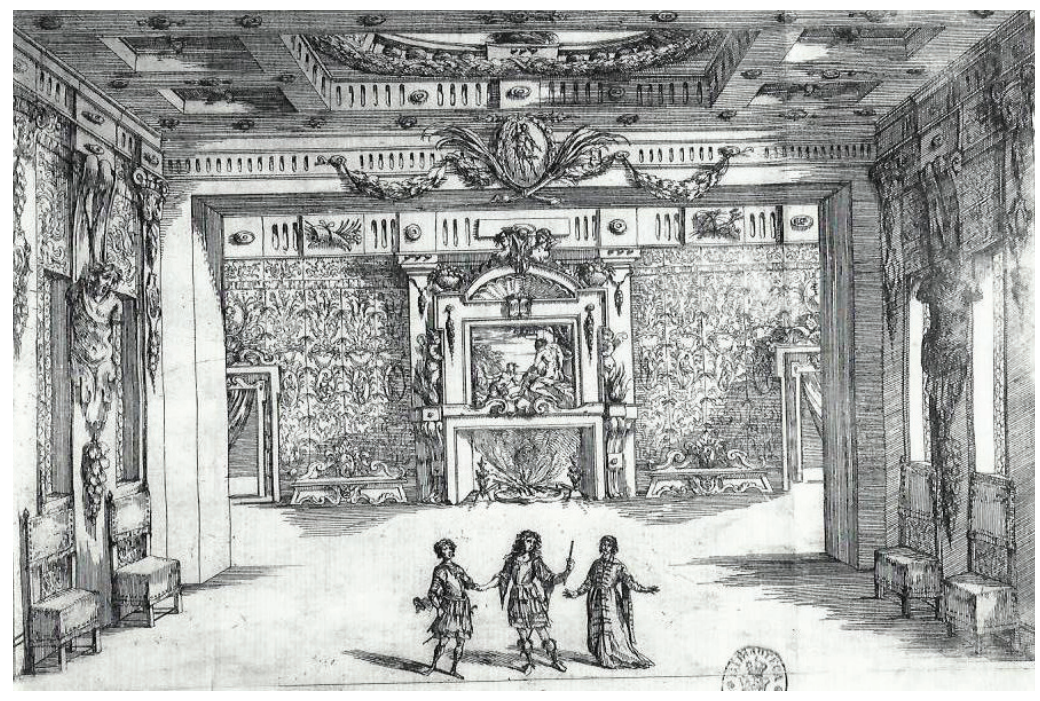

Fig. 4. Il Cromuele. Sala Regia. G. Graziani. Bolonia 1671. BNE.

22 Daniela SMALZI, "Giulio Parigi architetto di corte: la progettazione dell'ampliamento di palazzo e piazza Pitti”, en Mario BEVILACQUA, Architetti e costruttori del Barocco in Toscana. Opere, tecniche, materiali, Quaderni Atlante del Barocco in Italia, Centro di Studi sulla Cultura e 1'Immagine di Roma e Università degli Studi di Firenze, Dipartimento di Architettura, Disegno, Storia e Progetto, Roma, Luca Editore 2010, pp. 69-87.

23 Marinella PIGOZZI, "Il Cromuele di Girolamo Graziani e Prospero Manzini” en Maurizio FAGIOLO y Bruno ADORNI, Barocco romano e barocco italiano. Il teatro...op. cit., pp. 192-203. Aqui se recogen noticias como la citada sobre distintos episodios de la Historia Reggiana, como el Estratto del Diario dei Bernardino Rosati e della Cronaca di Antonio Denaglia, manuscritos de la Biblioteca Municipal, reunidos por P. FANTUZZI. Ver también C. RICCI, I teatri di Bologna nei secoli XVII e XVIII, Bologna 1888 . G. CROCIONI, I Teatri di Reggio Emilia, Reggio Emilia 1907. F. MAROTTI, Lo spazio scenico. Teorie e tecniche scenografiche in Italia dell'età barocca al Settecento, Roma 1974. 
En la nota de los impresores a los lectores de la obra que aquí se analiza, Il Cromuele, se les advierte de que se trataba de una Tragedia "di nuova moda", creada a partir de uno de los "accidentes más dignos de compasión del siglo...que habrán de inspirar el horror", donde se encuentre quizás uno de los primeros argumentos de justificación de tan particular obra, en previsión apotropaica o intimidatoria y a manera de exempla contra posibles movimientos revolucionarios semejantes. Una especie de cortafuegos simbólico en la senda de trágicas apologías similares, ideadas en el pasado de nombres ilustres que se citan a manera de autoridades morales y literarias al tiempo, como Ariosto u Homero.

La acción se desarrollaba en una única ciudad, caracterizándose a diferencia de otras obras similares precisamente por esa unidad de lugar, de manera que la composición escenográfica estaba concebida para aumentar la diversidad con presentación de diferentes ambientaciones, especialmente espléndidos o majestuosos, y lo que es más raro aún, en el contexto coetáneo de la obsesión perspectiva impuesta por Torelli en sus estudios escenográficos para la ilustración de las óperas venecianas, perfilándose tan sólo en una de las estampas el estudio de profundidad espacial que, sin embargo, en el resto de los diseños escénicos tienden a acotarse.

La historia se ambientaba por tanto en Londres, presentándose en la ilustración de la primera escena tres personajes de la enrevesada trama: Edmondo, quien realmente era Delmira, dama de la reina de Inglaterra, que se creía hija de Orinda, y que realmente lo era de Cronwell y de su esposa Elisabeth. Junto a Anna, hija de Odoardo Hide que fuera Gran Canciller, como Duquesa de York. Y la tercera en discordia, Orinda, dama viuda confidente de Elisabeth, la mencionada consorte del "tirano". La acción se desarrollaba en primer plano del proscenio y la mímica tiende a acentuar el gesto melodramático aunque particularizado en cada uno de los personajes, especialmente contenida en la figura del rey, que buscaba precisamente al contrario que el resto, la atenuación de signos dolorosos para recalcar la nobleza de sus actos. Y, en polo opuesto, más violentos y sanguinarios los movimientos de Cronwell, de la misma forma que resultan especialmente patéticos los de Enriqueta y Edoardo. En todos los casos, desde luego, posturas de amplia teatralidad y pausada lentitud que pretendían la mayor expresividad de los caracteres. A través de los grabados se percibe una concepción del vestuario "all'antica", pese a relatar un tema contemporáneo, que se explicaba por la identificación de dicha configuración del traje de la Antigüedad clásica con el género trágico por excelencia.

Desde el punto de vista del análisis escenográfico, no hay un interés excesivo por acentuar la profundidad perspectiva, más al contrario se trata de composiciones especialmente "encerradas" en la caja escénica con tendencia al bloqueo uniforme entre paramentos laterales y trasero, que en este caso, en la presentación de los primeros personajes, estaba constituido por un gran telón de fondo, con una especie de transepto previo, un pasillo de entrada y salida en correspondencia con dos vanos recortados enmarcando lo que algunos han denominado un "arcoscenico interno" 24 , mezcla de chimenea y escena figurada sobre ella sobre repisa rematada

24 Cesare MOLINARI, Le nozze degli dèi. Un saggio sul grande spettacolo italiano nel Seicento, Roma 1968, p. 132. 
de venera entre parafernalia decorativa de puttis o angelotes. Friso toscano que sustituía el bucráneo por algo parecido a cornucopias y más arriba festones de guirnaldas coronado todo el espacio figurado por un lucernario abalaustrado abierto en la cubierta de enormes casetones, que recuerdan a la configuración del altar primigenio del megaron de los palacios de los príncipes del mundo prehelénico. La sobrecarga decorativa hasta el "horror vacui" es excelsa con todo ese mismo paramento recubierto de floresta vegetal dispuesto a manera de candelieri más depurado sin embargo en los tramos laterales en los que tan sólo resaltan unos fantasmagóricos estípites figurados también que parecen retorcerse en idéntico gesto escorzado. Para empezar resulta sumamente impactante y los personajes parecen "engullidos" por la aparentemente sencilla decoración.

A diferencia de los deleites de virtuosismo perspectivo en los que van anclando los prototipos escenográficos, en la Florencia y Venecia de la segunda mitad del siglo XVII especialmente, en este caso se suplía la riqueza de la ampliación espacial en la lejanía por una cercanía del desarrollo de la acción con la zona de la embocadura.

Pese a las tardías fechas, entrando en el último cuarto de siglo, en líneas generales, todo el diseño compositivo del montaje escenográfico parece remitir a modelos franceses de cuadrícula cerrada, anteriores a los experimentos de virtuosismo óptico de Torelli, importados por el veneciano a la corte gala, que desembocaron en vistas ficticias y radicales perspectivas angulares de los Bibbiena. De hecho, puede que tal deuda estilística quedara explicada por la estrecha y dilatada relación, política y personal, entre el Ducado y la Corona de Francia, tal y como se ha podido comprobar en los vericuetos de la Dedicatoria de la obra. Por eso mismo quizás, las decoraciones planeadas para la representación que se aprecian en los grabados ilustrativos, de mesurada contención, muestran una mayor sintonía con las creaciones de artistas franceses no tan conocidos como Georges Buffequin ${ }^{25}$. El realismo en la representación hasta de los detalles decorativos de cornisas y demás elementos arquitectónicos derivan de la gramática ornamental, por otra parte habitual del binomio Colonna-Mitelli.

A diferencia de la articulación del espectáculo italiano, en el que no faltaban las prototípicas escenas representativas de los elementos, tierra, aire, mar y fuego, en esta ocasión los diseños propuestos transitan por otros derroteros, si bien es cierto que si se vislumbra la composición habitual en base al giardino, regulado y pautado, de raigambre apolínea, sin subrayar el salvajismo dionisíaco extremadamente cautivador y sorprendente, que trenza hasta los troncos de especies arbóreas, poblado de seres fantásticos en la senda de los monstruos como el de Pratolino, que hacían furor en los espectáculos italianos.

25 Marc BAYARD, Feinte baroque. Iconographie et esthétique de la varietés au XVIIe siècle, Collection d'histoire de l'arte, Acadèmie de France à Rome-Villa Medicis, París 2010. 


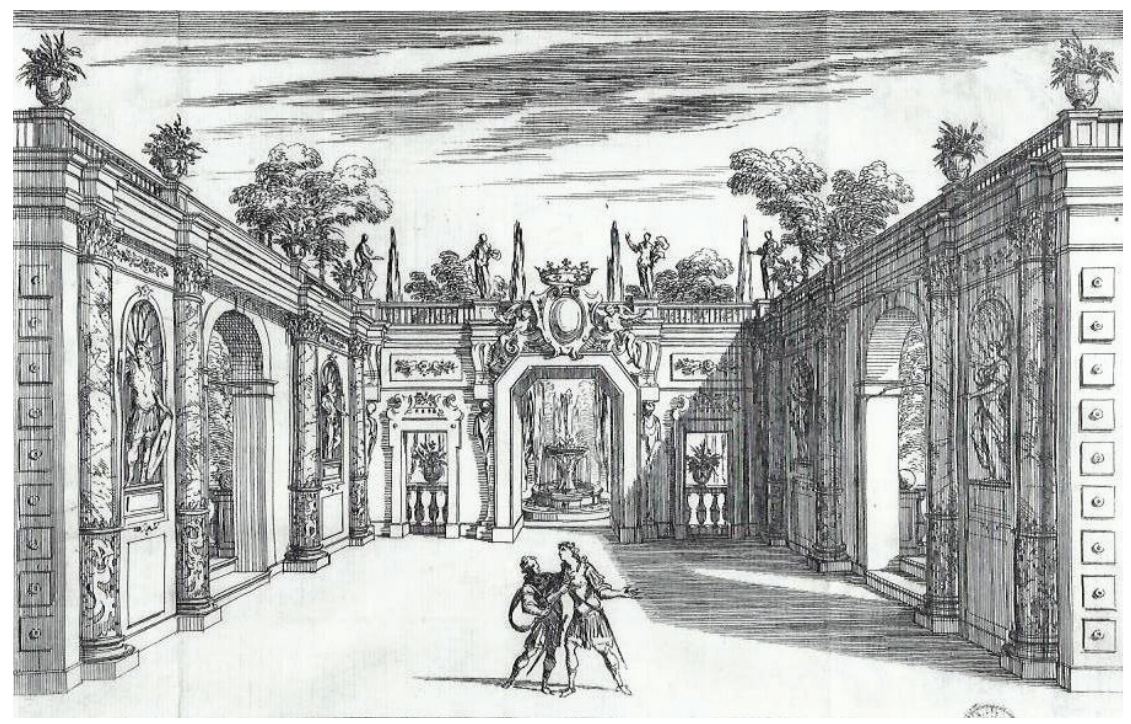

Fig. 5. Il Cromuele. Cortile Regio. G. Graziani. Bolonia 1671. BNE.

A lo largo de la Escena Tercera se va exponiendo la doctrina política: "al tuo Nome Anglia s'inclina..." le dice Lamberto a Cromwell y Harrison seguidamente cuenta que "Cesare usurpa, e Cronwel la rende...". El propio aludido no se confía demasiado con respecto a la usurpación de la capacidad regia, preparando el camino de la pena capital, cuando afirmaba que "e ancor ci resta. Da sudar sotto l'armi. Vive nel cuor de molti verso il Nome real l'antico affetto ${ }^{26} . . . "$ En este sentido, el carácter del puritano se va perfilando a ojos de los espectadores cuando en su boca dice el personaje que "intempestiva a vittoria imperfecta è la clemenza [...] Meglio dunque sará, che Carlo mora, perche viva la pace in Inghilterra..." y sin solución de continuidad se narra la desposesión cuando el mismo Cromwell remata que "Fù già Rè, più non è che un prigioniero ${ }^{27}$..."

Se exponían a continuación los argumentos que explicaban la Guerra Civil, de la misma forma que la arrogancia despótica del rey se convertía en la demostración de las acciones que llevaron a su arresto. Así, decía Cronwell que "il cor di chi comanda fidi solo à se stesso [...] Chi contra il suo signor la spada strinse non la deponga mai che con la vita [...] Farò servir le leggi à mi disegni, contra Carlo il giuditio è già introdotto... ${ }^{28 "}$ " La suerte del monarca estaba ya decidida.

La decoración escenográfica ajardinada es la escogida para ambientar la narración del Acto Segundo, en el que se elabora una de las tramas de la intriga. En esta ocasión se esbozan los personajes de Henrico, que en realidad esconde bajo el disfraz a la reina Enriqueta, en su diálogo con Edmondo. A través de las andanzas descritas, el es-

26 Acto primero, escena tercera. Lamberto, Cromuele, Harrissone, pp. 7-8.

27 Acto primero, escena tercera. Lamberto, Cromuele, Harrissone, pp. 8-10.

28 Acto primero, escena cuarta. Monólogo de Cromuele, pp. 12-13. 
pectador se entera de que la reina inglesa conspiró contra la autoridad parlamentaria, buscando el apoyo, no de la República Holandesa, sino del de Orange, emparentado por matrimonio con la familia real inglesa. Y también participan en el engaño Lady Anna, que ostentaba entonces el título de Duquesa de York y posteriormente llegó a ser la primera consorte del rey restaurado Jacobo II en 1685, hija de Odoardo o Edward Hide (1609-1674), que fuera Gran Canciller de Inglaterra en la realidad histórica y primer conde de Clarendon, exiliado en Francia donde falleció tras romper sus relaciones con el restaurado Carlos II.

Ha llovido mucho desde que Serlio estableciera las pautas de las decoraciones ajardinadas en base a la ilustración de la satírica escena vitruviana en un ámbito bucólico pastoril que facilitara la representación de una literatura de raigambre renacentista. En el jardín moraban las fuerzas telúricas y en ningún elemento mejor que en la naturaleza se explicitaba la mutabilidad de la metamorfosis, la trasmutación de espacios y caracteres que propician la confabulación de la trama. Por otra parte, la poética del espacio libre, a manera de idílica Arcadia, contrasta con el decorado de la cárcel, un refugio contra la injusticia. Más en este caso en que el jardín que se vislumbra tras el decorado a manera de celosía, aparecía en su forma ordenada, apolínea, como se dice de las decoraciones del francés Buffequin, con una vegetación "discreta" 29 . Lejos de alardes de fugas visuales torellianas y de torsiones arbóreas que presagiaban la columna salomónica, la representación del jardín que se propone se acercaba a la visión aristocrática y cortesana, artificiosa, de los escenógrafos franceses ${ }^{30}$, de los montajes del repertorio del Hotel Borgoña, el primer teatro parisino con el que se inició el siglo XVII. La arggucia amorosa ha dado paso a la confabulación política contra el tirano usurpador en este ámbito de locus amoenus propenso a la representación simbólica de la claridad de la civilización, del orden establecido por el gobierno regio y por eso en dicho ambiente se urde su liberación. Con una escenografía reducida a una forma cuadrangular e inteligible, con apenas una mínima concesión a la fuga perspectiva abierta a través del vano central, se favorecía la atención sobre la historia contada, la acción de los personajes en detrimento de la distracción de los juegos visuales. La mirada hacia el cielo, los gestos, la mímica melodramática, hasta patética, de los personajes remitían literalmente al Arte de cenni de Giovanni Bonifacio, convertido en manual de comportamiento extremadamente teatral de las distintas cortes italianas, que se exportan a través de representaciones como ésta. Y, quizás entre sus líneas se encontrara la inspiración del comportamiento intrigante de Enriqueta, una de las protagonistas de esta historia. Por tanto, alejadas las florituras perspectivas, la conclusión de la trama podría deducirse del carácter y de las acciones que desarrollaban cada uno de los personajes, que vuelven a tomar preeminencia en el frente del proscenio, al primer plano, más cercano a los espectadores de las escenas.

29 Marc BAYARD, Op. cit. p. 50.

30 Marc BAYARD, Op. cit. p. 53. "La forèt, pour une aristocratie urbaine du XVIIe siècle, correspond à un état passé, un souvenir uniquement réactualisé par la chasse. L'idée de nature, évolue du plaisir de la retraite à des considératio esthétiques, intellectuelles et pollitiques..." 
Todos ellos planeaban liberar al monarca encarcelado, pero Cronwell presintiendo ese desenlace ordena redoblar las medidas de seguridad en la prisión ${ }^{31}$, según planean en la representación de la Escena Tercera del Segundo Acto.

En la siguiente decoración que ilustra la escena del Segundo Acto, la acción se desarrolla en la ficción del interior de la Torre de Londres. Es en este caso uno de los que muestran un segundo plano paralelo a la boca del proscenio donde se ubican dos de los personajes del argumento ficticio. Así, frente a la pareja central, los otros dos personajes se sitúan en el lateral trasero y todos ellos amparados en una arquitectura imposible, enmarcados los primeros entre los gigantes zócalos de lo que simula el basamento en talud de algo parecido a un puntone o fortificación, cuadrangular el uno y circular el otro, interrumpidos en la parte superior. Pero, en todo caso una arquitectura grandilocuente, opresiva, piranesiana, de almohadillados sillares de labrada ejecución y decoración asimismo de mascarones con argollas, banderolas y trofeos, que antecedía al gran arco triunfal que enmarca el gran ventanal enrejado, con columnas jaspeadas adosadas. Y, que servía al propósito de Elisabetta, la mujer de Cromwell, encubierta bajo un velo, de asentarle la puñalada más certera al liberticida, declarando su amor al monarca preso.

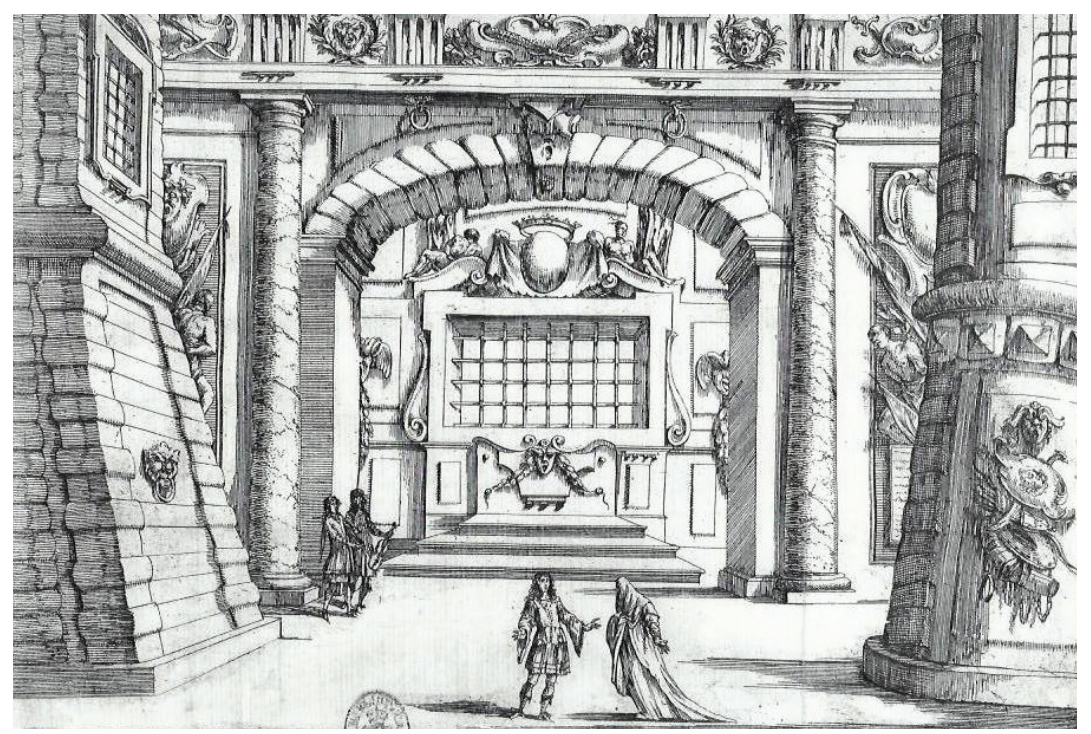

Fig. 6. Il Cromuele. Interior de la Torre de Londres. G. Graziani. Bolonia 1671. BNE.

En la Escena Octava del Cuarto Acto se encuentra el epígrafe que explicaba el cuarto grabado de la obra, para ilustrar lo que habría de ser el escenario de una Mascarada $^{32}$ y que transitaba por la misma senda estética de las perspectivas anteriormente descritas, de arquitecturas "imposibles", de ecléctica y heterodoxa configuración.

31 Acto segundo, escena tercera, p. 40. “...e sia trattato qual Rè ne 1'apparenza, e reo ne i fatti..."

32 Acto cuarto, escena octava, p. 103. Elisabetta con seguito di una Mascherata, Rè \& Arturo sù la Torre. 
En el lateral derecho, de hecho se mantiene la conexión con la imagen anterior, la vista interior de la prisión, en este caso, con el rey y su carcelero asomados a un balcón abierto en los muros de la torre-linterna, para contemplar el baile protagonizado por la consorte de Cronwelll. Alejada la composición, nuevamente, de arriesgados enfoques ópticos, más bien remite a los postulados clarificadores de Serlio, con bastidores laterales, de entrantes y salientes para estructurar la volumetría del marco escénico. Aunque es la única que permite una cierta fuga visual fluida hacia el fondo, la vista de un puente, tras el que varias edificaciones, una de ellas cupulada, en nada recordaban a la geografia histórica del Londres en el que supuestamente se desarrollaba la trama, como el resto de la panorámica en su conjunto parece insertarse en una voluntaria artificiosidad puramente escenográfica.

\author{
"Nella Sala Maggiore à la gran danza \\ La curiosa turba impatiente. \\ Tutto aplaude al trionfo, \\ tutto serve à $i$ comandi \\ Del mio invitto consorte[...] \\ Adornàte, rendete \\ La pompa trionfal sempre più cara[...] \\ Fortuna, che trionfa, che gode, \\ E col moto del piede unito il core \\ Tutto spiri allegrezza, e spiri amore."
}

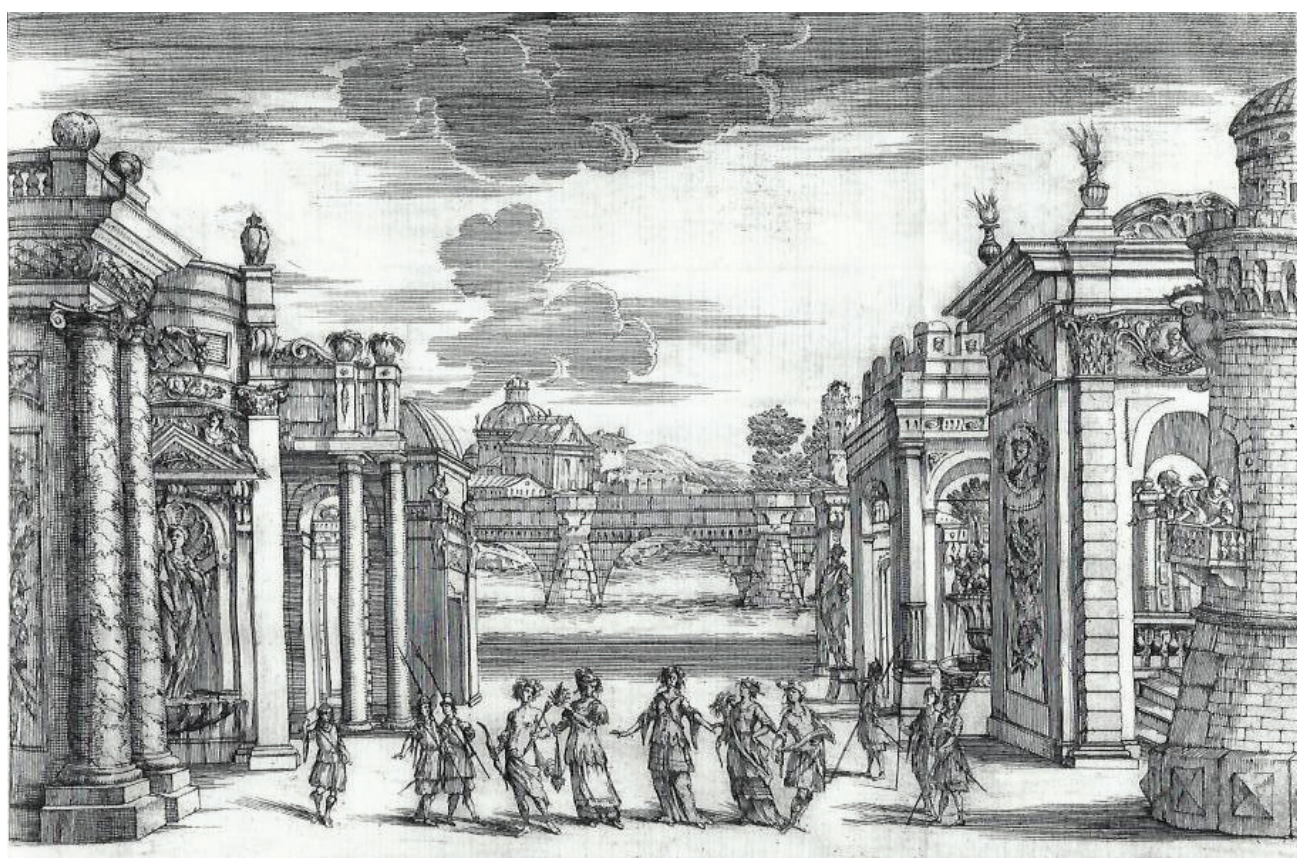

Fig. 7. Il Cromuele. Vista de Londres delante de la Torre. G. Graziani. Bolonia 1671. BNE. 
La alegre poética del baile coreografiado es el paso previo, inmediatamente anterior a la última aparición regia antes de su ejecución, en cuyo texto aún caben las últimas críticas contra los verdugos. Unas palabras que se convertían en implícita advertencia genérica contra el despotismo ilegítimo, como cuando decía el rey que "l'accortezza é perfidia, e non prudenza, se non regola il senno, l'ardire è ferità, che non conduce a dignitá sublime..." Hasta su postrera despedida en la que juraba haber alcanzado la felicidad del sufrimiento con honor y dignidad ${ }^{33}$. La historia del aciago Acto remataba con las vicisitudes en las cuales Orinda, la viuda confidente de Elisabeth, la mujer de Cronwell, delataba a su vez la conjura para salvar al rey ideada por Anna y Edoardo Hide, acción por la que hubieron de salir a la fuga de las iras del puritano, exiliándose en Francia.

No falta tampoco la escena de interior de los aposentos, de la Cámara Privada ${ }^{34}$. En este caso, tras la verdadera embocadura de la composición a manera de gran arco de Proscenio, en el fondo posterior, lo que se aprecia remitía más a la habitual cesura de la disposición arquitectónica palatina francesa del lecho regio, detrás de la balaustrada sobre las que se recorta la figura sedente.

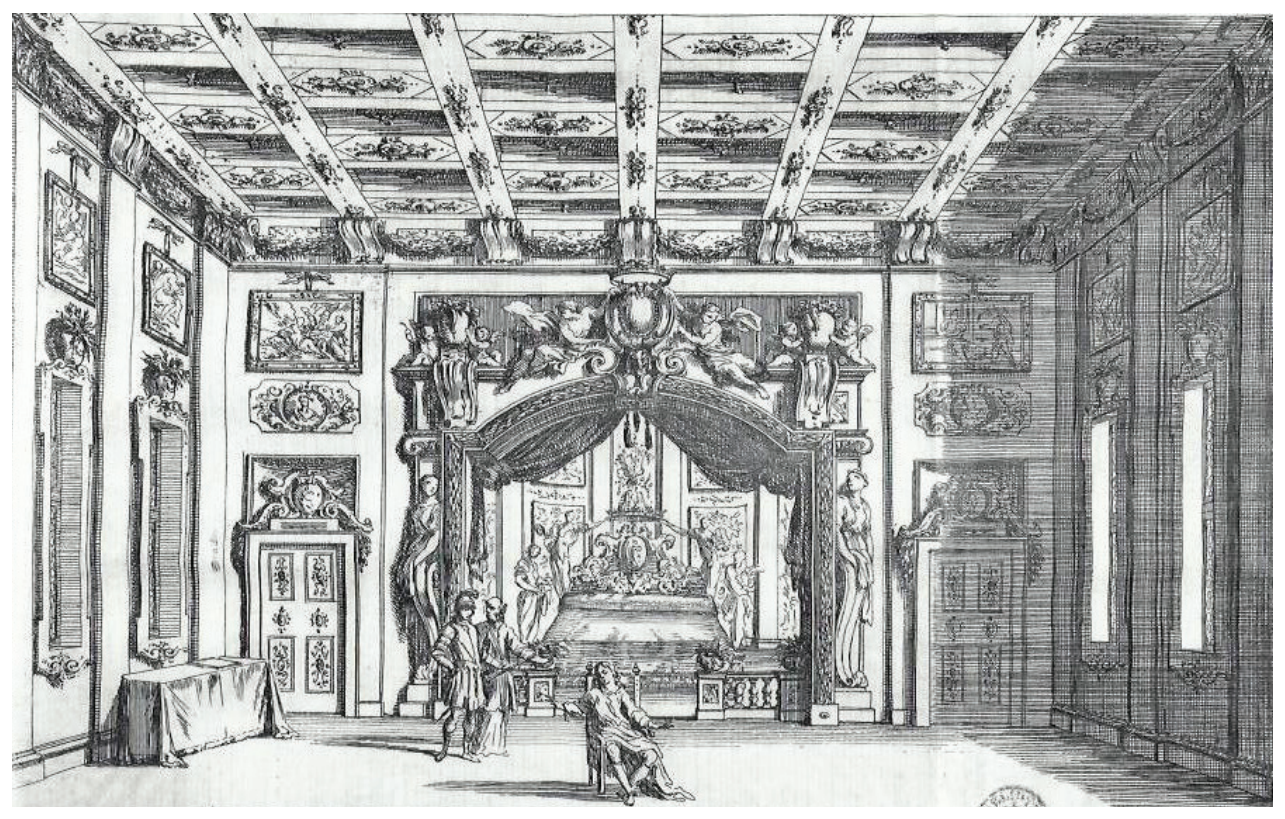

Fig. 8. Il Cromuele. Estancia de Cromwell. G. Graziani. Bolonia 1671. BNE.

\footnotetext{
33 Acto cuarto, escena novena, p. 106.

"E dio resto più lieto/Di sofreír con lode,/Che di gioir con bisogno, e sempre vago/

De la Virtù ne la Virtù mi appago."

34 Acto quinto, escena undécima. "Se apre la Prospetiva, in mezo alla quale si vede Cromuele, che asisso sopra una sedia dorme, e vicini in disparte sono Harrisone, e Lamberto", p. 145
} 
La amplia estancia enmarcaba los sueños de Cronwell, justo en el centro, que guardaban sus dos consejeros de confianza, Harrison, consigliere y Lamberto, el comandante de su ejército. Le estaban asegurando que no debía preocuparse tras la muerte del monarca, que su poder estaba consolidado, firmemente asentado, pero no logran tranquilizar los temores del liberticida, que se revolvía en un largo monólogo, mostrando si inquietud porque "ritornerà sù l'usurpato Trono; la tua Consorte, e $i$ figli tuoi depressi [...]" e incluso anticipándose a los nefastos presagios de la profanación de su cadáver que "sarà d'infamia eterna col tuo corpo dannato anche il tuo nome $^{35}[\ldots]$ ".

Con todo, la sentencia moralizante, la verdadera conclusión, la pronuncia Lamberto, en las últimas palabras de la obra, cuando declamaba así:

\author{
"Quinci apprenda ciascun quanto è fugace \\ Felicità terrena. \\ Vegga quanto s'inganna \\ Chi crede stabilir regno sicuro \\ Su fundamento incerto. \\ La coscienza rea \\ Basta sola per far misera un'alma; \\ Scettro non vale, e non tesoro, e lice \\ A la sola Virtù render felice ${ }^{36}$."
}

Por otro lado, esta escenificación de la cámara privada palatina, frecuente en las composiciones escenográficas del Seicento, de ascendencia torelliana y traducción de conveniencia edilicia en los aposentos de la arquitectura francesa regia, reconocible en el estilo artístico en la órbita de Luis XIV, incidía en la verosimilitud del gusto afrancesado imperante en la corte esténse, del que incluso existía un ejemplo similar en el Palazzo Masdoni, donde se llevó a cabo la representación de la obra.

Composición escénica contenida frente a expresión de sentimientos y motivos psicológicos de los personajes parece ser la conclusión a la vista del análisis de todas las escenas a través de los grabados que se incluyen en el libreto. La restitución del espacio vuelve por sus fueros a recuperar dimensiones reales, y la escenografía retoma su carácter complementario, en este caso, de la acción humana. La representación parecía haber recuperado un tanto la estabilidad de los llamados "cuadros" del temprano Renacimiento de la Historia del Espectáculo. Interiores profusamente decorados al gusto francés, arquitectura barroca contenida de raigambre depurado y clasicista, junto a dramáticas poses en la gestualidad predominan en la expresión escénica.

En los primeros años del siglo XVII se mencionaba al arquitecto Giovanni Ambrogio Magenta, seguidor en cierta moda de los postulados del también boloñés Pellegrino Tibaldi, como principal exponente de la herencia de artistas del Cinquecento locales, como Doménico Tibaldi o Pietro Florini. Representantes todos de una arqui-

35 Acto quinto, escena undécima, p. 147.

36 Acto quinto, escena última, p. 160. 
tectura menos ilusionística que la reflejada en los diseños escenográficos de Torelli, Mauro y los Burnacini. Así que los diseños del Cromwell se identificaban más con el estilo boloñés, anticipando temática arquitectónica escénica de Marco Antonio Chiarini, sin la exaltación perspectiva decantada en mayor medida por la mímica de los personajes, en la que los actores venían a suplir la función de maquinaria y aparatos, tal y como se puede comprobar en dos de las decoraciones por él ideadas para $L a$ forza della Virtù en 1694 y para Il Nerone fatto Cesare en 1695. El Barroco Emiliano llegó a caracterizarse por la grandeza de los espacios marco aunque en correspondencia con la coherencia orgánica, a la manera del clasicismo depurado que también sintonizaba con el perfil florentino. Grandeza en los vanos, sumado al valor de muros como pantalla sobre la que proyectar la particularidad local, la "quadratura" en la que hicieron fortuna las creaciones de sus más hábiles representantes, Colonna-Mitelli, en una conjunción dinámica de decoración y columnas fingidas.

Y llegados a este punto, no queda sino abordar el asunto de la autoría. Se conocen los nombres de otros artistas habituales en las decoraciones de festejos de la corte modenesa, como Giacomo Monti y Baldassarre Bianchi, aunque a quien se propone como inventor de la escenografía del Cromuele es a Prospero Manzini, que figuraba por esas fechas como "apparatore" 37 , activo en Reggio, Modena y Bolonia, y que estilísticamente estaba próximo a los diseños que se ilustran en los grabados anteriormente descritos.

Se le calificaba como "pittore di cuadratura d prospectiva, valente per far Machine, scene, teatri e altro". Según otras fuentes, también se le mencionaba directamente como discípulo de Agostino Mitelli. A su vez, padre del pintor y decorador Cesare, como abuelo de Raimondo Manzini, miembro de la Academia Clementina en 1723, sin embargo había sido olvidado por la historiografía de la Escenografía como manifestación de Arte Efímero, hasta la magna obra de Fagiolo sobre el Barroco Italiano, que recoge por capítulos toda la Historia del Espectáculo del país vecino y que supone una impresionante reivindicación del significado de los eventos y formatos plásticos que abarca tal concepción estilística.

Repasando entonces, las nuevas alusiones al personaje, se le atribuía la construcción de maquinaria, arcos y carros triunfales para distintas festividades locales, civiles y religiosas. Multiplicidad profesional, por otra parte habitual entre las virtudes del escenógrafo, se vincula a Manzini en la decoración del Teatro Formagliari (1641), inventor de toda la parafernalia para la ambientación de la Feste fatte in Bologna in occasione del Pubblico e Solenne Ottavario della Canonizzazione di S. Filippo Beniti en 1671, de la misma forma que figura en 1673 su nombre en las decoraciones teatrales para la famosa fiesta local de la Porchetta, lo que muestra su dilatada actividad en este campo. Pero, más expresamente, en la línea de las decoraciones escenográficas de grandes dramas como el de Cromwell, aquí analizado, se aludía a Prospero Manzini para la ilustración del libreto de Giovan Battista Giardini y música de Prospero Manzi, titulado Il Principe Corsaro, editado en Módena en 1674. De la misma forma que se le atribuían las creaciones escenográficas para La Schiava Fortu-

37 Marinella PIGOZZI, "Il Cromuele di Girolamo Graziani e Prospero Manzini" en Maurizio FAGIOLO y Bruno ADORNI, Barocco romano e barocco italiano. Il teatro...op. cit., p. 197. 
nata, en el Teatro de la Spelta y en el Teatro del Público en Bolonia en 1680, en base al texto de Andrea Moniglia y música de Antonio Cesti, ambos dos, bien conocidos por ser los autores del macrofestejo Il Pomo d'Oro, con el que se conmemoraba el matrimonio del emperador Leopoldo I con la Infanta Margarita Teresa, en Viena, en 1665 , e ilustrado con decoraciones, entonces en ese caso, de los Burnacini. No sería descabellado, por tanto, relacionar a Manzini con todos estos dramas alegóricos de numerosos personajes mitológicos, por su experiencia en la dinámica tipología de la escenografía barroca, de múltiples simbologías, mutaciones, apariciones y complemento de maquinaria. En definitiva, Manzini ${ }^{38}$ parecía estar en perfecta consonancia con la obra de conocidos y afamados escenógrafos emilianos como Carlo Virginio Draghi y Ludovico Vigarani. Y como representante de una tendencia menos profusa en los excesos perspectivos que ostentaron otros protagonistas de su generación, en la cultura figurativa de la zona, como los Galli Bibiena, Ferdinando y Francesco. Decantado, sin embargo por el vocabulario derivado del binomio Colonna-Mitelli, con idéntica capacidad para las composiciones grandilocuentes pero lógicas, exuberantes pero verosímiles en el sentido orgánico de su arquitectura ilusoria, todo lo cual hace más que presumible su autoría en la creación de los diseños escenográficos de esta obra, Il Cromuele, tan notable como excepcional en la gramática de la Escenografía Italiana de finales del siglo XVII.

38 Marinella PIGOZZI, “Il Cromuele di Girolamo Graziani...”, op. cit., pp. 197-203. 